\title{
Entrepreneurship Learning through Pramuka Activity
}

\author{
Dulatip ${ }^{1}$, Ifit Novita Sari ${ }^{2}$, Dwi Fita Heriyawati ${ }^{3}$ \\ Universitas Kanjuruhan Malang1, Universitas Islam Malang2,3 \\ inovsari@unisma.ac.id
}

Article History:

Received: June $12^{\text {th, }} 2020$

Revised: August $13^{\text {th }} 2020$

Accepted: September 30th, 2020

\begin{abstract}
Pramuka is a form of non-formal education that becomes a place in the implementation of Pramuka education. In Pramuka activities, its members are trained with various skills, including leadership, discipline, self-confidence, mutual help, and independence. Its activities are generally carried out in the open with fun, interesting, directed activities by the basic principles and Pramuka methods. In general, Pramuka activities are only filled with the same activities, but in Sudirman Kalipare High School, Malang Regency has innovations for Pramuka as extracurricular activities by incorporating entrepreneurial learning. As a result, students are increasingly honed in their creativity and find a breakthrough to developed into an entrepreneurial venture with low capital and maximum results. Jendral Sudirman High School Scout Contingent won 1st place in the Sangga Putri Business Plan in the Pramuka Achievement Competition in the Bali-Bali Level VIII 2019.
\end{abstract}

Keywords-component; entrepreneurship; extracurricular activities; pramuka

\section{INTRODUCTION}

The manuscript should be saved in a doc file. Please do not send your manuscript In the Law of the Republic of Indonesia Number 12 Year 2010 Concerning Scout Movement Chapter III Article 5 states that Pramuka education is carried out based on values and skills to shape Scout's personality and life skills (Pramuka, 2010). Pramuka is a non-formal educational movement, voluntary, nonpolitical, open to all, without differentiating origin, race, ethnicity and religion (Ambri, 2017). Pramuka is now important in developing the nature of patriotism and nationalism among teenagers. In these activities can foster a sense of togetherness and mutual respect. Pramuka also plays a role in channeling students' talents and interests, forming the character and personality of students, such as being able to shape the discipline in each of its members. The purpose of pramuka activities is to educate and foster students to develop mental, moral, spiritual, intellectual students to become a good generation and useful for themselves, their families, nations and countries (Ariani, 2015). In Pramuka 
activities there is a process of character building and the development of students' skills to become a formidable and noble young generation. Ambri further explained that the goals of Pramuka education are: 1) to shape the character of young people so that they have character, personality and noble character, 2) instill a spirit of nationalism so that young people love the country and have a spirit of national defense, and 3) equip young people with various skills and skills (Ambri, 2017).

Currently entrepreneurial learning is rife by education units and tertiary institutions as additional skills for students and students to be later able to open their own jobs. Entrepreneurship can be defined as risk taking to run one's own business by taking advantage of opportunities to create new businesses or with innovative approaches so that managed businesses develop into large and independent companies in facing competition challenges (De Jong \& Wennekers, 2008). That is the reason behind Jendral Sudirman High School (JS High School) to choose Pramuka as an optional and compulsory extracurricular activity, as stipulated in the Regulation of the Minister of Education and Culture of the Republic of Indonesia Number 63 of 2014 Regarding Pramuka Education as a Compulsory Extracurricular Activity in Basic Education and Secondary Education (Ambri, 2017).

Since 1994, Pramuka activities have been initiated at this school and trained by Indonesian Language teachers who love Pramuka. Beginning Scout activities are held which are not extracurricular must only be interested by 6 students. However, these activities are still carried out following Pramuka activities' rules, although there are few enthusiasts. The persistence of Scout trainers who continue to carry out Scout activities is gradually producing results with the increasing number of Scout members in JS High School. The development of Pramuka activities at the school was carried out in various ways including participating in various Pramuka competitions which were widely held from the District to National level. The title was also widely won by JS High School in the field of Pramuka. With the issuance of Ministerial Regulation No. 63 of 2014 which states that Pramuka Education as a compulsory extracurricular activity in primary and secondary education, JS Senior High School also implements the regulation and makes Pramuka activities a compulsory extracurricular for class $\mathrm{X}$ and continues to accommodate Scout groups that already exist as selected extracurricular for class X and XI. Scout activities as extracurricular activities at JS High School are carried out with the actualization and regular models. The extracurricular activities are compulsory at regular hours in the first and second school hours every Saturday, while Pramuka as an extracurricular choice is carried out every Saturday after teaching and learning activities in schools starting from 13:00 until 15:00 WIB. 


\section{METHOD}

This research uses a case study research method with a qualitative approach. Data obtained through interviews, observation and supporting documentation data. Researchers are the instruments themselves armed with interview guides that have been set according to the focus of the study.

\section{RESULTS AND DISCUSSION}

Pramuka activities at JS High School became a strength for the school because it had many achievements both at the Regency and National levels. Referring to Ministerial Regulation Number 63 Year 2014 JS High School also carries out Pramuka activities as mandatory extracurricular activities. Because being extracurricular is compulsory, grade $\mathrm{X}$ students are required to take part in the activity. As for students of class XI who have an interest in participating in Pramuka activities, they are accommodated in selected extracurricular activities

\section{Pramuka as Extracurricular}

The objectives of extracurricular activities in the education unit are: 1) extracurricular activities must be able to improve students' cognitive, affective, and psychomotor abilities, and 2) extracurricular activities must be able to develop the talents and interests of students in the efforts of personal coaching towards full human development (Permendikbud number 63 of 2014). When the Boy Scouts extracurricular started at JS High School, there were still relatively few enthusiasts, because students were more interested in activities that were playful, such as volleyball, soccer and basketball. But the coach and trainer have a strong determination, intention and enthusiasm to keep the activity going. After three years of running students begin to see what activities are in the Boy Scouts extracurricular and the number of participants starts to increase from 6 to 12, 20 and until now the members range from 90-100 people. So that extracurricular activities are not monotonous and boring, in addition to being held at school the trainer invites members to do activities outside the school (outdoor) by inviting other trainers. These activities are liked by students because their activities are relaxing, but there is much useful knowledge that they can learn. The material taught starts from basic about rigging, semapur, morse, setting up tents, and First Aid in Emergency Room (PPGD). In addition to physical activity they are also taught about the values of life how to work together in solving a problem and find a solution, help each other, respect others, provide stimulation so that creativity and leadership appear so that students grow in self-confidence

It was explained that extracurricular activities are activities that are carried out outside the classroom and outside class hours to develop and develop the potential of human resources (HR) owned by students, both related to the 
application of knowledge they obtain or in a special sense to guide students in developing potential and talent that exists in him through activities that are mandatory and optional (Dewi \& Saragih, 2015). JS High School uses Scout extracurricular as a means to develop students' potential and talents because in their activities, there are many activities related to the development of both physical and psychological skills. In Pramuka activities there is also a process of developing students' personality traits. They are taught how to solve problems faced either together with the group or individually. The values of cooperation, responsibility, respect for others' opinions, discipline, and confidence indirectly appear in Pramuka activities. Scouts can also shape a person's character. Such as can form the nature of discipline in each of its members. The Scout's purpose is to educate and foster adolescents to developmental, moral, spiritual, educated youth to be good and useful young people (Ariani, 2015).

In the Regulation of the Minister of Education and Culture of the Republic of Indonesia number 63 of 2014 governed the implementation of mandatory extracurricular scouts in schools. There are three implementation models namely block, actualization and regular models. JS High School applies two models, namely the Actualization model for compulsory Scout extracurricular for class X and the Regular model for selected extracurricular for classes X and XI. An explanation of the three models of Scout extracurricular implementation along with the nature and organization of their activities is explained in the table below.

Table 1

Model Of Extracurricular Implementation Of Scout Mandatories In School

\begin{tabular}{|c|c|c|c|}
\hline No. & Model & Nature & Organizing Activities \\
\hline 1 & Blok & $\begin{array}{l}\text { Mandatory, once a year, } \\
\text { applies to all students, } \\
\text { scheduled, } \\
\text { general assessment }\end{array}$ & $\begin{array}{l}\text { - Collaborative } \\
\text { - Are intramural or } \\
\text { extramural (outside and } \\
\text { inside the educational unit } \\
\text { environment) }\end{array}$ \\
\hline 2 & Actualization & $\begin{array}{l}\text { Mandatory, routine, } \\
\text { scheduled, } \\
\text { applies to all students in } \\
\text { each class, scheduling, and } \\
\text { formal assessment }\end{array}$ & $\begin{array}{l}\text { - Scoutmaster } \\
\text { - Are intramural (in an } \\
\text { educational unit } \\
\text { environment }\end{array}$ \\
\hline 3 & Regular & Voluntary, interest based & Fully managed \\
\hline
\end{tabular}

Source: Regulation of the Minister of Education and Culture of the Republic of Indonesia number 63 of 2014

JS High School Scout extracurricular activities are routine and active, so that they can win various competitions at the district, provincial and national levels. 
Even the Front Cluster (Gudep) JS High School Scouts become a reference for the surrounding schools because they remain active in their activities. Elementary School (SD) which is in the same district as JS High School asked the help of a trainer to train extracurricular elementary school children around. Even elementary schools from neighboring sub-districts also asked for the help of a trainer from JS High School. The trainers sent are students who become Scout members in selected extracurricular who have Scouts' basic abilities and are considered capable of training in elementary school. Each school is trained by 3 members of JS High School Scouts. From the results of the primary school principal's assessment asking for help to be trained, it shows that Scout members from JS High School are able to train and foster students who take extracurricular activities at elementary school. From basic Pramuka skills to exemplary examples of how to behave and respect each other.

The function of extracurricular activities in the education unit has the functions of development, social, recreational, and career preparation (Ambri, 2017). The function of development, the Boy Scout extracurricular activities at JS High School functions to develop students' personality through the development of interests, potential, and providing opportunities in shaping the character of students and leadership training for students. Social functions, Scout extracurricular activities at JS High School function to develop self-confidence, care for others and students have a sense of social responsibility. Recreational functions, Boy Scout extracurricular activities at JS High School are carried out in a relaxed, joyful, and fun atmosphere so that students do not feel under pressure. The function of career preparation, Boy Scout extracurricular activities at JS High School functions to develop students' career readiness through capacity building, it is proven that JS High School is a reference for elementary schools around asking trainers for their extracurricular activities.

\section{Entrepreneurship in Scout Extracurricular}

After Permendikbud number 63 of 2014 emerged about Pramuka education as a compulsory extracurricular activity in primary and secondary education, the new JS High School set Pramuka as a compulsory extracurricular in 2016. Extracurricular must be followed by all class X students and carried out at regular learning hours, every Saturday the first and second hours. Extracurricular material must contain Pramuka theory, standard Pramuka practices such as rigging, semapur, morse, setting up tents, and First Aid in the Emergency Department (PPGD). Class X students are required to take part in Pramuka activities and are also allowed to take part in extracurricular activities as a choice. To avoid the similarity and boredom of the Scout activities material, the idea of entrepreneurship taught at the Boy Scout extracurricular will be given every Saturday at $13.00-15.00$ WIB. 
To distinguish which extracurricular are compulsory and optional, entrepreneurial learning is applied to introduce students to entrepreneurship. Starting with collecting used paper then weighed and sold, but it has not been creative, then changed to make products. They were beginning to make a product by trying simple and many students already know how to make ice popsicles. Activities are made in groups to compete in terms of ice popsicles' taste, but these activities are still lacking because there are no challenges for students. Then try some other products that start from making innovative banana chips and jam, a combination of pineapple and banana with the product name Sekupibonas. Jam processing is fairly simple and traditional and there is no preservative mixture. Teachers assist in laboratory testing of nutritional value in the fields of Chemistry and Biology. The results were very encouraging because the jam was able to win 1st place in the Sangga Putri Business Plan in the Pramuka Achievement Competition in the Java-Bali Level XVII.

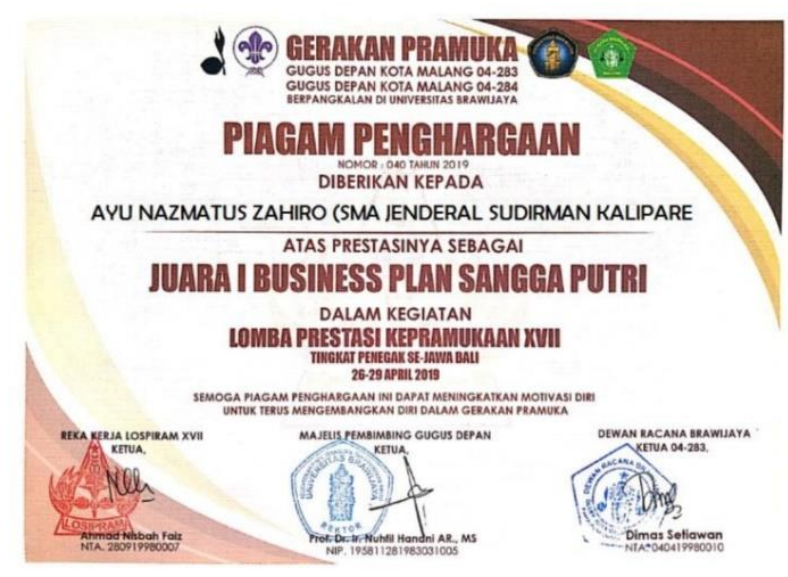

Fig. 1. Championship Charter

JS High School facilitates students to take part in competitions from district to national level to train students to compete with other schools and gain valuable experience and achievements in various competitions. With the development of entrepreneurial activities, the coach and coach feel the shortage of capable workers in the field of entrepreneurship. Collaboration with teachers in other fields of study has been carried out, but it is still considered lacking due to the limitations of human resources and supporting facilities for entrepreneurial activities, especially those that are related to manufacturing products. During this time the means of manufacturing activities and product practices were carried out at the home of one of the students who have adequate facilities to practice product manufacturing. 


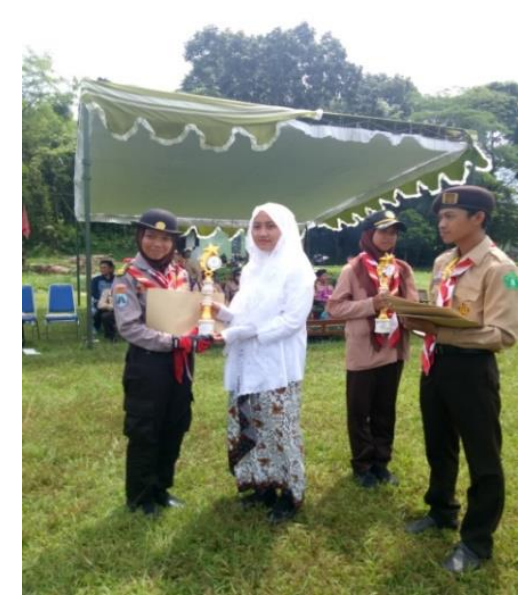

Fig. 2. Sangga Putri Business Plan 1st prize winner

In its development in the future JS High School needs assistance from various parties who can help smooth the entrepreneurship program in Scout extracurricular activities. In the future, there will be collaboration with JS High School alumni who do not continue their education to a higher level and have not yet worked. Collaboration with related parties and academia will also be carried out so that the entrepreneurship program in Pramuka activities as an extracurricular choice can continue and bring additional skills to students. JS High School hopes that students will be able to be independent and brave to start entrepreneurship even though they are still at the Senior High School level to add pocket money and additional income for their families. Entrepreneurship programs in education can be implemented in the following ways: (1) integrating entrepreneurship education into all subjects, teaching materials, extracurricular activities and self-development activities, (2) developing educational curricula that provide entrepreneurial education content and being able to increase understanding of entrepreneurship, fostering entrepreneurial character and skills, and (3) fostering a culture of entrepreneurship in the school environment and the environment of students to increase family income (Adji, 2016).

JS High School is committed to providing the best service for its students. The school's location, which is far from the city center and in the Kalipare subdistrict, does not dampen the lofty desire that students can align with students in the city, both with the ability in terms of knowledge and competency in the skills of students. Entrepreneurial spirit is needed by students, if this is always given by the teacher as a stimulant then indirectly in the brains of students will be embedded in thinking about entrepreneurship, and when adult students will get used to their independence and creativity so they are able to create new opportunities (Adji, 
2016). Entrepreneurship serves as the ability to create change, renewal and progress in certain fields, and not only used as a short-term effort, but can also be used as a long-term effort in life in general. Pramuka education can enhance the strengthening of entrepreneurship-based character education (PURI, 2019).

\section{CONCLUSION}

Several conclusions were obtained from the discussion and findings of research on entrepreneurial learning through Pramuka extracurricular activities at JS High School. First, the purpose of Pramuka extracurricular activities at JS High School is to improve students' cognitive, affective, and psychomotor abilities, as well as to develop students' talents and interests in efforts to foster students' personalities. Second, JS Senior High School applies two Pramuka extracurricular implementation models, namely the Actualization model for Boy Scouts extracurricular mandatory for class $\mathrm{X}$ and the Regular model for selected extracurricular activities for classes X and XI. Third, JS High School became a reference for the surrounding elementary schools to ask for help from the trainer in the Boy Scout extracurricular activities at his school. Fourth, to distinguish compulsory extracurricular activities, entrepreneurial learning is applied to the Scout extracurricular choices to introduce students to entrepreneurship. Fifth, the products of entrepreneurial learning results can compete and excel in national level competitions. Sixth, it needs to be reviewed for continuing the entrepreneurship learning next to the builder, facilities and infrastructure for the manufacture of products characteristic of JS JSS. Seventh, it needs help from outsiders from alumni and experts who are competent in their fields to succeed in learning entrepreneurship to compete in the market. Eighth, the application of entrepreneurship education is taught in specific subjects and integrated in every subject taught, extracurricular activities, and self-development activities.

\section{ACKNOWLEDGMENT}

This research was supported by a grant Thesis Magister from the Minister of Directorate Higher Education of Indonesia (DRPM DIKTI).

\section{REFERENCES}

Adji, W. S. (2016). PENANAMAN NILAI-NILAI KEWIRAUSAHAAN.

Ambri, S. (2017). Pramuka ekstrakurikuler wajib di sekolah. Jurnal Ilmu Keolahragaan, 13(2), 16-21.

[Ariani, D. A. D. (2015). Manajemen Ekstrakurikuler Pramuka. Manajer Pendidikan, 9(1). 
[De Jong, J., \& Wennekers, S. (2008). Intrapreneurship; conceptualizing entrepreneurial employee behaviour. EIM Business and Policy Research.

Dewi, N. K., \& Saragih, S. (2015). Pengaruh Kegiatan Ekstrakurikuler Kepramukaan Terhadap Perilaku Prososial Remaja Di SMP Santa Ursula Jakarta. Persona: Jurnal Psikologi Indonesia, 3(03).

PURI, N. (2019). PEMANFAATAN PRAMUKA SEBAGAI PENDIDIKAN KARAKTER BERBASIS KEWIRAUSAHAAN. JEET-Journal of Education, Entreprener and Training, 2(1). 